\title{
REGENERATION THROUGH RESPROUTING AFTER CLEAR-CUTTING AND TOPSOIL STRIPPING IN A TROPICAL DRY FOREST IN CENTRAL BRAZIL ${ }^{1}$
}

\author{
Maxmiller Cardoso Ferreira ${ }^{2 *}$, Silvia Barbosa Rodrigues ${ }^{3}$ and Daniel Luis Mascia Vieira ${ }^{4}$ \\ ${ }^{1}$ Received on 04.03.2016 accepted for publication on 28.03.2017. \\ ${ }^{2}$ Universidade de Brasilia, Mestrado em Ecologia, Distrito Federal, Brasilia, Brasil . E-mail: <maxmiler.bio@gmail.com>. \\ ${ }^{3}$ Universidade de Brasilia, Programa de Pós-Graduação em Ecologia, Distrito Federal, Brasilia, Brasil. E-mail:<silviabrodri@gmail.com>. \\ ${ }^{4}$ Laboratório de Ecologia e Conservação, Embrapa Recursos Genéticos e Biotecnologia, Distrito Federal, Brasilia, Brasil. \\ E-mail:<daniel.vieira@embrapa.br>. \\ *Corresponding author. \\ ABSTRACT - Tropical dry forest trees have high resprouting ability, which may be useful for ecological \\ restoration purposes. However, resprouting ability is affected by the type and severity of the disturbance. \\ This study described the regeneration of trees through resprouting in a seasonally deciduous forest in Central \\ Brazil, six months after being subjected to a gradient of disturbance. In order to expand a limestone quarry, \\ 10 ha of deciduous forest were deforested in May 2013, creating areas with three increasing levels of disturbance: \\ Clear-Cutting, Stump Removal and 5-20 cm of Topsoil Stripping. Twenty $3.14 \mathrm{~m}^{2}$ circular plots were randomly \\ selected in each type of disturbance. All resprouts were counted and identified to species level. The plant \\ organ where each resprout grew from and the distance of the resprout insertion to the soil were recorded. \\ There were 27 species in the Clear-Cutting and Stump Removal areas, and 24 in the Topsoil Stripping site. \\ Resprout density was $3.0 \pm 0.3^{\mathrm{a}} / \mathrm{m}^{2}$ in the Clear-Cutting, $1.7 \pm 0.4^{\mathrm{b}}$ in the Stump Removal and $1.4 \pm 0.4^{\mathrm{b}}$ \\ in the Topsoil Stripping area (mean \pm SD; Tukey HSD). Stems contributed to $61 \%$ of the resprouts in the \\ Clear-Cutting area, while $60 \%$ of the resprouts in Stump Removal grew from root collars and $70 \%$ of the \\ resprouts in Topsoil Stripping grew from roots. Underground resprouts emerged from a depth of up to 24 \\ $\mathrm{cm}$. An increase in disturbance severity negatively affected resprouting ability, but natural regeneration was \\ high regardless of disturbance severity. The high resprouting ability of the deciduous forest trees provides \\ resilience even after topsoil stripping.
}

Keywords: Natural regeneration; Resilience; Seasonally deciduous forest.

\section{REGENERAÇÃO VIA REBROTA APÓS CORTE RASO E REMOÇÃO DA CAMADA SUPERFICIAL DO SOLO DE FLORESTA ESTACIONAL DECIDUAL NO BRASIL CENTRAL}

\begin{abstract}
RESUMO - Arvores de floresta estacional decidual possuem grande capacidade de rebrota, que pode ser utilizada para sua restauração. Porém, a capacidade de rebrota é afetada pelo tipo e severidade da perturbação. Este estudo descreveu a regeneração via rebrota de árvores em uma floresta estacional seis meses após ser submetida a um gradiente de aumento de perturbação, no Brasil Central. Na expansão de uma cava de mineração em maio de 2013, 10 ha de floresta estacional foram desmatados e formaram-se três níveis crescentes de distúrbio: corte raso, destoca e remoção de $5-20 \mathrm{~cm}$ da camada superficial do solo. Foram alocadas ao acaso em cada tipo de distúrbio 20 parcelas circulares de $3,14 \mathrm{~m}^{2}$, nas quais foram contadas e identificadas as espécies rebrotando, e avaliada a altura de inserção e o órgão responsável pela rebrota. A área de corte raso e destoca apresentaram 27 espécies e a remoção de solo 24 (curvas de rarefação). A densidade de rebrotas $/ m^{2}$ foi 3, $0 \pm 0,3^{a}$ no corte raso, $1,7 \pm 0,4^{b}$ na destoca e $1,4 \pm 0,4^{b}$ na remoção de solo $(M \pm D P$; Tukey HSD). Tocos contribuíram com $61 \%$ das rebrotas no corte raso, colos $60 \%$ na destoca e raizes $70 \%$ na remoção de solo; rebrotas subterrâneas emergiram de até $24 \mathrm{~cm}$ de profundidade. O aumento da severidade do distúrbio afetou negativamente a capacidade de rebrota, porém, a regeneração natural foi alta nos três distúrbios. A alta capacidade de rebrota das árvores de florestas deciduais confere resiliência mesmo diante de distúrbios que removem o solo superficial.
\end{abstract}

Palavras-chave: Regeneração natural; Resiliência; Floresta estacional decidual. 


\section{INTRODUCTION}

Tropical dry forests are one of the most threatened terrestrial ecosystems on the planet (Murphy and Lugo, 1986; Griscom and Ashton, 2011). They represent an estimated $42 \%$ and $22 \%$ of the tropical forests around the world and in South America, respectively (Murphy and Lugo, 1986; Griscom and Ashton, 2011). These forests have a discontinuous distribution in Brazil; they are found both within the Cerrado savanna formations and Caatinga xerophytic formations of the central and northeastern regions of the country and within the evergreen forest formations of the Amazon and Atlantic Forest, in northern and southern Brazil (Scariot and Sevilha, 2005). Despite their widespread distribution in Brazil, dry forests have been neglected by national conservation and restoration policies (Scariot and Sevilha, 2005; Haidar, 2008). In the Cerrado biome, deciduous forests grow on highly fertile soils derived from limestone rocks and, as a result, they are being replaced by agriculture (Scariot and Sevilha, 2005) and limestone mining (Haidar, 2008). There are few forest remnants left in the Federal District, since the vegetation has been converted into pastures and large limestone quarries (Semarh, 2005).

Disturbances are natural or anthropogenic events that alter the structure and functioning of the ecosystem. After a disturbance that removes aboveground biomass, tropical deciduous forests regenerate primarily through root and stem resprouting (Kennard et al., 2002; Vieira et al., 2006). The existence of a dry season (Sampaio et al., 1993; Bond and Midgley, 2001), fires that originate from neighboring grasslands and savannas (Vieira and Scariot, 2006a), and slash-and-burn agriculture, practiced for millennia by native peoples (Mazoyer et al., 2010), are all factors that exert selective pressure for a strong resprouting ability in these forests. Many dry forest tree species persist by resprouting after disturbances such as fire (Sampaio et al., 1993; Kennard et al., 2002), slash-and-burn agriculture (Ruiz et al., 2005), selective logging (Griscom and Ashton, 2011) and forest-to-pasture conversion (Vieira et al., 2006; Sampaio et al., 2007).

Resprouting ability is preserved in intact or partially damaged stems and roots, but decreases with increasing disturbance severity (Vieira and Scariot, 2006a): resprouting buds are lost as damage to stems and roots increases (Bellingham and Sparrow, 2000; Bond and Midgley, 2001). In addition, in dry forests major disturbances tend to select species with higher resprouting ability (Vieira and Scariot, 2006a). In Bolivia, for instance, a dry forest exposed to a low intensity fire had a higher density of resprouts and more stem resprouts than a forest exposed to a high intensity fire, where root resprouts were more prevalent (Kennard et al., 2002). Understanding the mechanisms through which an ecosystem becomes resistant or resilient to disturbance is important to develop restoration strategies. Some examples are knowing which species are capable of resprouting after major disturbance and which do not have this ability and need to be reintroduced in restoration areas, or using resprouting ability as a tool for passive restoration.

In order to better understand the natural regeneration of a seasonally deciduous forest after disturbance, this study evaluated resprouting ability of a forest subjected to three types of disturbance with increasing levels of severity: (1) Clear-Cutting, (2) Stump Removal and (3) Topsoil Stripping. The goals of this study were to (i) assess species richness and composition and density of resprouts, and (ii) evaluate the role of different resprouting organs (root, root collar, or stem) six months after the disturbance.

\section{MATERIALAND METHODS}

\subsection{Study area}

The study was carried out between May and November 2013 at a site in the Fercal administrative region, in the north-central region of the Federal District of Brazil (DF) (15³4'S, 47 53'W; elevation 990 m). Mean annual precipitation is $1,495 \mathrm{~mm}$ ( $\mathrm{min}-$ max range $1,157-$ $1,948 \mathrm{~mm}, 1990-2015$ series), and $93 \%$ of the rainfall is concentrated between October and April. The mean temperature of the hottest month is $22.7^{\circ} \mathrm{C}$, and of the coldest month is $19.2^{\circ} \mathrm{C}$ (INMET, 2015). The soil is a highly fertile Cambisol originated from predominantly calcareous rocks of the Paranoá group (ZEE-DF, 2009). The vegetation is secondary seasonally deciduous forest mata seca decídua sensu (Ribeiro and Walter, 2008), which is markedly deciduous in the dry season and has a canopy height of around $20 \mathrm{~m}$ and a basal area of $22 \mathrm{~m}^{2} / \mathrm{ha}$ (Haidar, 2008). The forest studied is bordered by semi-deciduous forests on slopes, cerrado stricto sensu on less fertile Cambisols, cerradão in interfluvial areas and gallery forests along watercourses. The region is characterized by the presence of many secondary forests remnants, pastures in the lowlands 
and large limestone quarries that supply the Federal District with cement (SEMARH, 2005).

\subsection{Vegetation removal and characterization of disturbance}

In May 2013, 10 ha of secondary forest were clearcut to allow for the expansion of the Cimento Tocantins limestone quarry, owned by Votorantim Cimentos. Stumps were removed along skid roads, and the topsoil was stripped from part of the area. The resprouting ability of the vegetation was evaluated in three types of disturbance that occurred simultaneously. ClearCutting: most of the woody vegetation $<10 \mathrm{~cm} \mathrm{DBH}$ was removed with a brush hook in preparation for using a chainsaw. Afterwards, all woody vegetation $\geq 10$ cm DBH was cut with a chainsaw. Stump Removal: a bulldozer opened roads to haul tree trunks to the log deck; the blade was positioned at soil level to remove stumps, thin stems and leaf litter. The use of heavy equipment on the roads was limited to the hauling period. Topsoil Stripping: about four hectares of topsoil were removed to initiate the limestone mining operation. A bulldozer stripped between 5 and $20 \mathrm{~cm}$ of the soil, along with tree trunks, thin stems, litter and superficial roots.

\subsection{Sampling the regenerating vegetation}

Six months after the disturbance (November 2013), we randomly established 20 circular plots with a $1 \mathrm{~m}$ radius in each of the three types of disturbance. In each plot, all resprouting stems were counted and identified. Resprouts were classified according to their organ of origin: (i) stems (resprouts from stumps or thin stems); (ii) root collars; or (iii) roots (lateral or taproot); underground resprouts were dug up to determine their origin. In order to evaluate the height of insertion of aerial resprouts, and the depth of insertion of subterranean resprouts, the distance between the first resprout and the soil level was measured with a ruler. Resprouts of the same species within a $30 \mathrm{~cm}$ radius were considered the same individual. Specialists of the Embrapa Genetic Resources and Biotechnology herbarium (CEN) helped identify specimens that could not be identified on the field.

\subsection{Data analysis}

In order to determine which tree species were the main resprouters in the three types of disturbance, we sorted species by their absolute and relative densities. We evaluated differences in tree resprout richness between the three types of disturbance using rarefaction curves based on individuals (Gotelli and Colwell, 2001). We tested for differences in resprout density between the three types of disturbance using ANOVA. Our data satisfied the assumptions of homoscedasticity and normal distribution, verified using Bartlett and ShapiroWilk tests, respectively. Comparisons between pairs of means were carried out using a posteriori Tukey HSD tests. In order to evaluate differences in the proportional contributions of resprouting organs between the three types of disturbance, we used a Chi-square $\left(\mathrm{x}^{2}\right)$ test. We evaluated the distance from the resprout insertion point to the soil level by describing the median (1st and 3rd quartiles), minimum and maximum distances for each organ. All analyses were conducted in R ( R Core Team, 2015).

\section{RESULTS}

Six months after the disturbance, 41 tree species of 20 families were resprouting in the study areas. The main families were Fabaceae, with nine species; Malvaceae and Rubiaceae, with four; and Bignoniaceae and Myrtaceae, with three (Table 1).

\subsection{Number of species and density of tree resprouts}

The number of resprouting species did not differ between Clear-Cutting and Stump Removal areas, but there were fewer species in the Topsoil Stripping area (species richness rarefaction curves based on individuals; Figure 1a). The density of resprouts was significantly higher in the Clear-Cutting area, but it did not differ between Stump Removal and Topsoil Stripping $\left(\mathrm{F}_{(2,57)}\right.$ $=9.28 ; \mathrm{P}<0.001 ;$ Figure $1 \mathrm{~b}$ ).

\subsection{Contribution of different resprouting organs}

The source of the resprout varied with disturbance $\left(x^{2}=210.13\right.$; d.f. $\left.=4 ; \mathrm{P}<0.0001\right)$. Resprouts from stems dominated the Clear-Cutting area, and root collars and roots were more prevalent in the Stump Removal and Topsoil Stripping areas, respectively (Figure 2a). In the Topsoil Stripping area, $52 \%$ of resprouts originated from lateral roots and $18 \%$ from taproots. Resprouts from underground organs emerged from a depth of $24 \mathrm{~cm}$ of less, and stem resprouts emerged from a height of up to $80 \mathrm{~cm}$ above the soil level (Figure 2b).

Revista Árvore. 2017;41(2):e410218

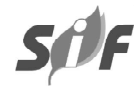



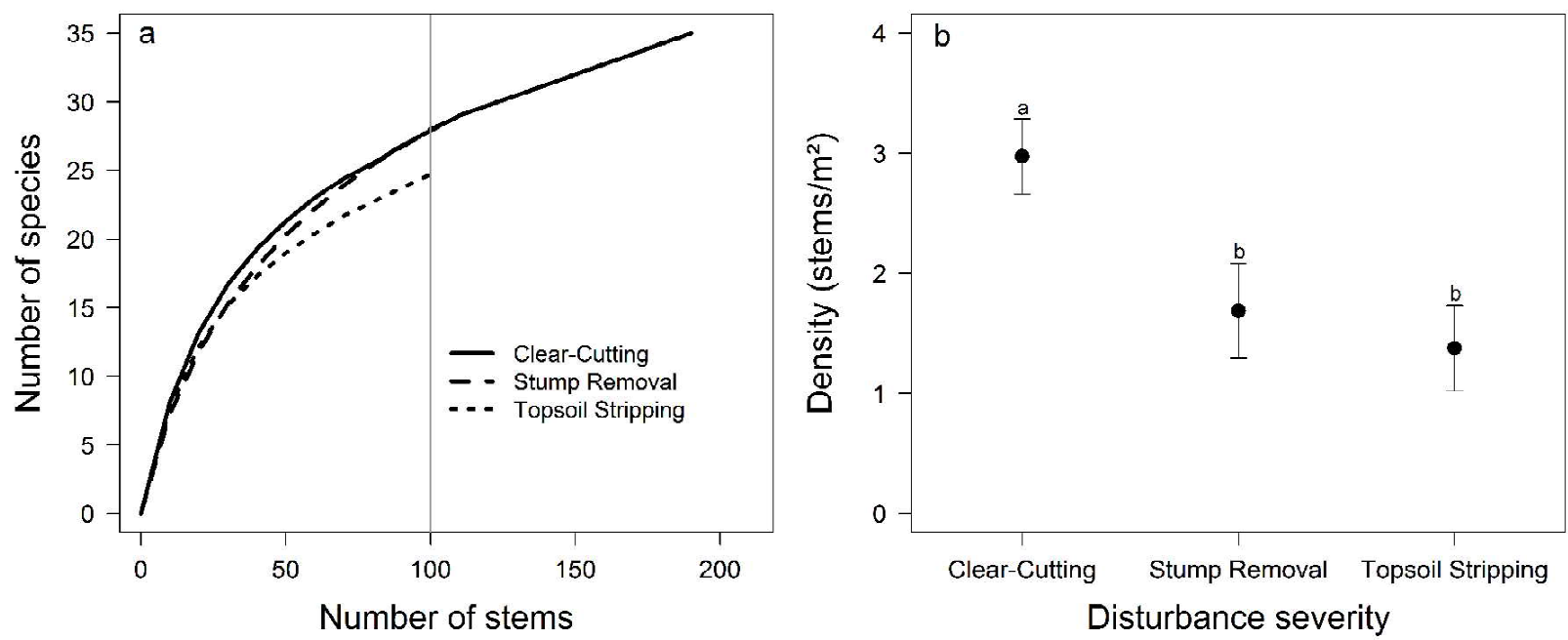

Figure 1 - Number and density of tree species resprouting in a seasonal deciduous forest in the Fercal Region, Federal District, six months after Clear-Cutting, Stump Removal and Topsoil Stripping. a, Species richness rarefaction curves based on individuals. b, Density of individuals $/ \mathrm{m}^{2}$; bars show means \pm 1 standard deviation, same letters indicate no significant difference between means using Turkey HSD, $\mathrm{P} \leq 0.05$

Figura 1 - Número de espécies e densidade de árvores rebrotando em uma floresta estacional decidual que sofreu corte raso, destoca e remoção da camada superficial do solo seis meses após os distúrbios, Região da Fercal, Distrito Federal. a, Curvas de rarefação espécies baseadas em indivíduos. b, Densidade de indivíduos $/ m^{2}$; barras são médias \pm 1 desvio padrão, letras iguais indicam ausência de diferença entre médias com teste a posteriori de Tukey $H S D, P \leq 0,05$.

\subsection{Main resprouting species}

The densities of Anadenanthera colubrina, Campomanesia velutina, Dilodendron bipinnatum, Guettarda viburnoides, Platymiscium floribundum and Sebastiania brasiliensis were high after all three types of disturbance. Aegiphila sellowiana, Diospyros brasiliensis, Myracrodruon urundeuva and Erythroxylum daphnites were very dense in the ClearCutting area, but densities were low in the Stump Removal and Topsoil Stripping areas. The densities of Cupania vernalis, Inga cylindrica and Machaerium hirtum were low in Clear-Cutting, but were more dense in Topsoil Stripping area (Table 1).

\section{DISCUSSION}

The resprouting ability of dry forest tree species was high, even after disturbances where a large share of the aerial biomass and resprouting buds had been removed. Between 25 and 35 tree species resprouted at densities of 1.4-3.0 trees $/ \mathrm{m}^{2}$, demonstrating that, even after topsoil stripping, natural regeneration was high. In addition, the lianas Mandevilla hirsuta, Banisteriopsis spp. and Serjania spp., and the shrubs Manihot anomala and Bauhinia spp., which were not sampled in the plots, were observed resprouting in the disturbed areas. Vigorous resprouts, between 0.5 and $1.5 \mathrm{~m}$ tall, were growing at high densities in all areas, which may promote rapid development of a canopy cover and trigger the forest regeneration process. This structure would offer better conditions, such as soil moisture and shade, for seed germination and seedling establishment of arriving species (Mclaren and Mcdonald, 2003; Vieira and Scariot, 2006b; Vieira et al., 2007).

\subsection{Severity of disturbance and resprouting ability}

The density of resprouting trees in Stump Removal and Topsoil Stripping areas was 51\% lower compared to area subjected to Clear-Cutting. We also found six fewer species in the Topsoil Stripping area, suggesting that increasing the severity of the disturbance had a negative effect on the regenerating community. The 

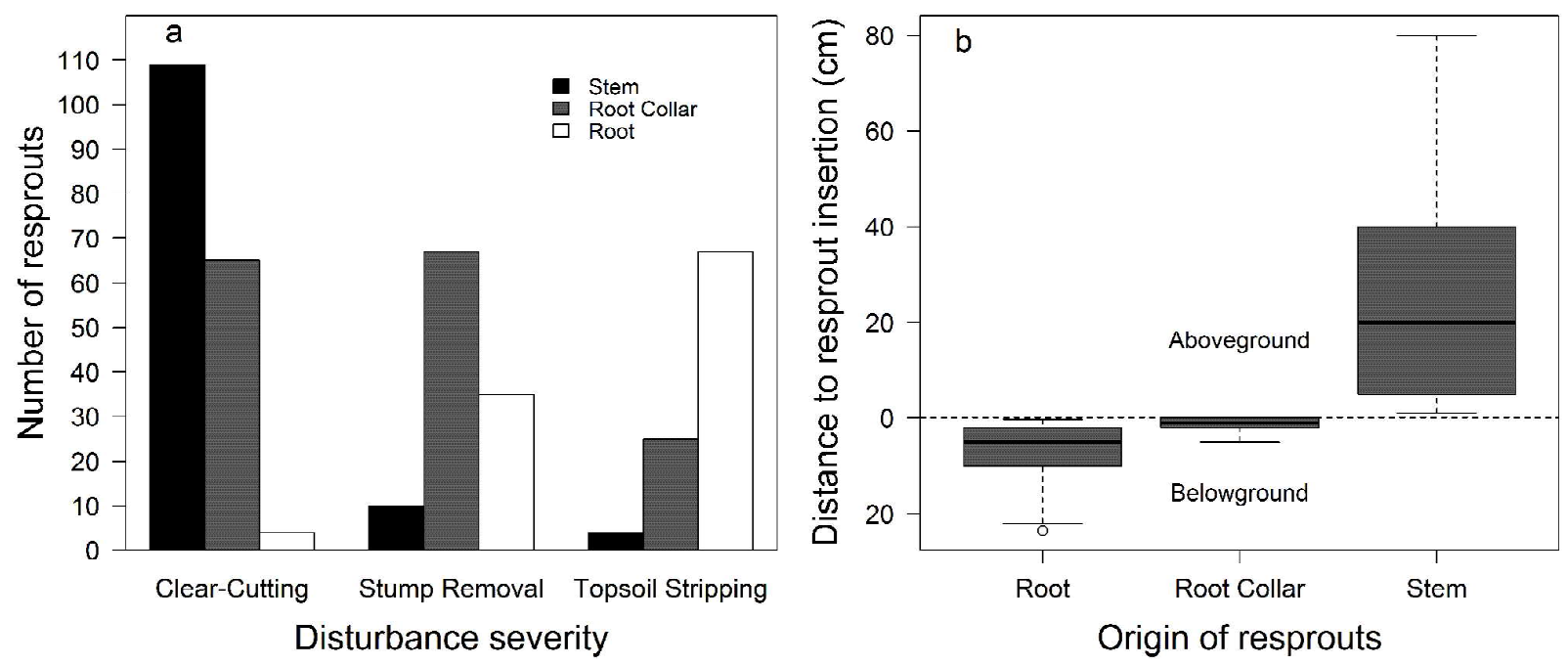

Figure 2 - Number of resprouts and distance to soil of resprout insertions in roots, root collars and stems in a seasonal deciduous forest in the Fercal Region, Federal District, six months after Clear-Cutting, Stump Removal and Topsoil Stripping. a, Absolute number of resprouts. b, Distance to the soil level of the resprout insertion point in the origin organ; the median is represented by the dark line in the center of the box, the box shows the 1 st and 3rd quartiles, and the whiskers show the maximum and minimum.

Figura 2 - Número de rebrotas e distância em relação ao solo da inserção das rebrotas na raiz, colo e caule em floresta estacional decidual que sofreu corte raso, destoca e remoção da camada superficial do solo seis meses após os distúrbios, Região da Fercal, Distrito Federal. a, Número absoluto de rebrotas. b, Distância de inserção das rebrotas no órgão de origem em relação ao solo; a mediana é representada pelo traço preto no centro da caixa, o $1^{\circ}$ e $3^{\circ}$ quartil os extremos da caixa e o máximo e mínimo são as barras.

reduction in richness and density was caused by the removal of stumps and the concomitant loss of the stem bud bank and, in the Topsoil Stripping area, the removal of the bud bank in root collars and superficial roots (Figure $3 \mathrm{a}-\mathrm{d}$ ). Other studies in tropical deciduous forests also suggest that resprouting ability decreases as damage to stems and collar roots increases, since these structures retain their ability to resprout from pre-existing buds or from buds that are produced after they are cut (Kennard et al., 2002; Mostacedo et al., 2009; Mcdonald et al., 2010). It should be noted, therefore, that the primary bud bank that is largely responsible for resprouting in tropical dry forests is in stems and root collars.

Tap and lateral roots partially compensated for the bud depletion caused by the removal of stems, or even superficial roots, from the Topsoil Stripping area. Our results suggest that, in the absence of taller stems and root collars, root resprouts become more prevalent, since there were nine and 17 times more resprouts from roots in Stump Removal and Topsoil Stripping, respectively, than in the Clear-Cutting area (Figure 2a). Both bud production and root resprouting may be induced by stress to ensure plant survival, and may also result in clonal propagation, if the resprout splits from the original plant (Del Tredici, 2001; Rodrigues et al., 2004; Hayashi and Appezzato-Da-Glória, 2009). Adventitious buds in roots represent a potential (secondary) bud bank that compensates for the loss of primary resprouting buds (Klimešová and Klimeš, 2007; Clarke et al., 2013). Thus, root resprouts are the last possible source of vegetative recovery in deciduous forests. In case of more severe disturbance, the resilience of these forests may be exhausted.

This study allows for an interpretation of the effects of the main types of disturbance of deciduous forests today. The conversion of natural vegetation into mechanized agriculture amounts to a very severe level of disturbance that exhausts the potential for vegetative regeneration. In these cases, the soil is prepared by 
Table 1 - Family, species, absolute (AD) and relative (RD, in \%) densities of trees/100 $\mathrm{m}^{2}$ resprouting in a seasonal deciduous forest in the Fercal Region, Federal District, six months after Clear-Cutting, Stump Removal and Topsoil Stripping. The top 10 densities in each type of disturbance are in bold.

Tabela 1 - Famílias, espécies, densidade absoluta (DA) e relativa (DR, em \%) de árvores $/ 100 \mathrm{~m}^{2}$ rebrotando em uma floresta estacional decidual submetida à corte raso, destoca e remoção da camada superficial do solo seis meses após os distúrbios, Região da Fercal, Distrito Federal. As 10 maiores densidades em cada distúrbio foram colocadas em negrito.

\begin{tabular}{|c|c|c|c|c|c|c|}
\hline \multirow[t]{2}{*}{ Family/Species } & \multicolumn{2}{|c|}{ Clear-Cutting } & \multicolumn{2}{|c|}{$\begin{array}{c}\text { Stump } \\
\text { Removal }\end{array}$} & \multicolumn{2}{|c|}{$\begin{array}{c}\text { Topsoil } \\
\text { Stripping } \\
\end{array}$} \\
\hline & AD & $\mathbf{R D}$ & AD & RD & AD & $\mathrm{RD}$ \\
\hline \multicolumn{7}{|l|}{ Anacardiaceae } \\
\hline Astronium fraxinifolium Schott & 12.7 & 4.0 & 6.4 & 3.4 & 3.2 & 2.1 \\
\hline Myracrodruon urundeuva Allemão & 19.1 & 6.1 & 1.6 & 0.9 & 1.6 & 1.1 \\
\hline $\begin{array}{l}\text { Bignoniaceae } \\
\text { Cybistax antisyphilitica (Mart.) Mart. }\end{array}$ & 3.2 & 1.0 & 3.2 & 1.7 & 1.6 & 1.1 \\
\hline Tabebuia aurea (Silva Manso) Benth. \& Hook.f. & 1.6 & 0.5 & 1.6 & 0.9 & 1.6 & 1.1 \\
\hline Jacaranda brasiliana (Lam.) Pers. & 1.6 & 0.5 & 1.6 & 0.9 & - & - \\
\hline $\begin{array}{l}\text { Celastraceae } \\
\text { Maytenus floribunda } \text { Reissek }\end{array}$ & 9.5 & 3.0 & - & - & 9.5 & 6.3 \\
\hline $\begin{array}{l}\text { Clusiaceae } \\
\text { Kielmeyera coriacea } \text { Mart. }\end{array}$ & - & - & 1.6 & 0.9 & - & - \\
\hline $\begin{array}{l}\text { Combretaceae } \\
\text { Terminalia phaeocarpa } \text { Eicheler }\end{array}$ & 9.5 & 3.0 & 8.0 & 4.3 & 3.2 & 2.1 \\
\hline Ebenaceae & & & & & & \\
\hline Diospyros brasiliensis Mart. ex Miq. & 17.5 & 5.6 & 4.8 & 2.6 & 1.6 & 1.1 \\
\hline $\begin{array}{l}\text { Erythroxylaceae } \\
\text { Erythroxylum daphnites Mart. }\end{array}$ & 15.9 & 5.1 & 6.4 & 3.4 & 1.6 & 1.1 \\
\hline Erythroxylum deciduum A.St.-Hil. & 3.2 & 1.0 & - & - & - & - \\
\hline $\begin{array}{l}\text { Euphorbiaceae } \\
\text { Sebastiania brasiliensis } \text { Spreng. }\end{array}$ & 25.5 & 8.1 & 8.0 & 4.3 & 4.8 & 3.2 \\
\hline $\begin{array}{l}\text { Fabaceae } \\
\text { Anadenanthera colubrina (Vell.) Brenan } \\
\text { Inga alba (Sw.) Willd. }\end{array}$ & $\underline{27.1}$ & 8.6 & 6.4 & 3.4 & $\begin{array}{l}\mathbf{8 . 0} \\
4.8\end{array}$ & $\begin{array}{l}5.3 \\
3.2\end{array}$ \\
\hline Inga cylindrica (Vell.) Mart. & 4.8 & 1.5 & 1.6 & 0.9 & 14.3 & 9.5 \\
\hline Lonchocarpus cultratus (Vell.) Az.-Tozzi \& H.C. Lima & - & - & 8.0 & 4.3 & 3.2 & 2.1 \\
\hline Machaerium brasiliense Vogel & - & - & - & - & 6.4 & 4.2 \\
\hline Machaerium hirtum (Vell.) Stellfeld & - & - & 1.6 & 0.9 & 12.7 & 8.4 \\
\hline Piptadenia gonoacantha (Mart.) Macbr. & 1.6 & 0.5 & 3.2 & 1.7 & - & - \\
\hline Platymiscium floribundum Vogel & $\mathbf{1 7 . 5}$ & 5.6 & 14.3 & 7.8 & 15.9 & 10.5 \\
\hline Swartizia acutifolia Vog. & 3.2 & 1.0 & 1.6 & 0.9 & 3.2 & 2.1 \\
\hline $\begin{array}{l}\text { Lamiaceae } \\
\text { Aegiphila sellowiana } \text { Cham. }\end{array}$ & 14.3 & 4.5 & 1.6 & 0.9 & - & - \\
\hline $\begin{array}{l}\text { Lythraceae } \\
\text { Lafoensia densiflora Pohl }\end{array}$ & 1.6 & 0.5 & 1.6 & 0.9 & - & - \\
\hline $\begin{array}{l}\text { Malvaceae } \\
\text { Guazuma ulmifolia Lam. }\end{array}$ & 3.2 & 1.0 & 1.6 & 0.9 & - & - \\
\hline Luehea divaricata Mart. & 1.6 & 0.5 & 3.2 & 1.7 & - & - \\
\hline Pseudobombax tomentosum (Mart. \& Zucc.) A.Robyns & 8.0 & 2.5 & - & - & 1.6 & 1.1 \\
\hline Sterculia striata A. St.-Hil. \& Naudin & - & - & - & - & 1.6 & 1.1 \\
\hline $\begin{array}{l}\text { Myrsinaceae } \\
\text { Rapanea guianensis Aubl. }\end{array}$ & 3.2 & 1.0 & - & - & - & - \\
\hline $\begin{array}{l}\text { Myrtaceae } \\
\text { Campomanesia velutina (Cambess.) O.Berg } \\
\text { Myrcia tomentosa (Aubl.) DC. }\end{array}$ & $\begin{array}{c}25.5 \\
8.0\end{array}$ & $\begin{array}{l}8.1 \\
2.5\end{array}$ & $\begin{array}{c}38.2 \\
1.6\end{array}$ & $\begin{array}{c}\mathbf{2 0 . 7} \\
0.9\end{array}$ & $\begin{array}{c}\mathbf{1 2 . 7} \\
1.6\end{array}$ & $\begin{array}{l}8.4 \\
1.1\end{array}$ \\
\hline
\end{tabular}

Revista Árvore. 2017;41(2):e410218 
Table 1...

Tabela 1..

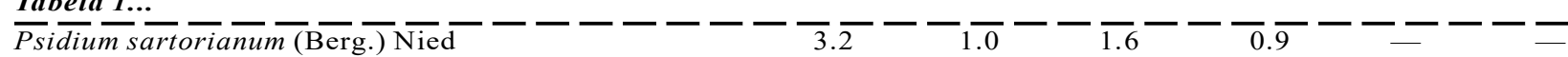

Proteaceae

Roupala brasiliensis Klotzsch

Rubiaceae

Alibertia edulis (Rich.) A.Rich. ex DC.

Cordiera sessilis (Vell.) Kuntze

Guettarda viburnoides Cham. \& Schltdl.

Tocoyena formosa (Cham \& Schltdl) K. Schum.

Rutaceae

Zanthoxylum rhoifolium Lam.

Sapindaceae

Cupania vernalis Cambess.

Dilodendron bipinnatum Radlk.

$1.6 \quad 0.5$

$11.1 \quad 3.5$

$3.2 \quad 1.0$

$22.3 \quad 7.1$

$6.4 \quad 2.0$

$3.2 \quad 1.0$

$1.6 \quad 0.5$

$20.7 \quad 6.6$

$1.6 \quad 0.5$

$1.6 \quad 0.5$

hysiaceae

Qualea multiflora Mart.

removing the stems, plowing the soil and manually removing roots and underground stems from the top $30 \mathrm{~cm}$ of soil (Rezende et al., 2005; Sena and Pinto, 2008); this material is then piled up and burned (Figure $3 \mathrm{c}-\mathrm{e})$. Even if roots and underground stems persist, deep in the soil, resprouts only seem to emerge from a depth of up to $24 \mathrm{~cm}$ (Figure 2b), suggesting that, vegetative structures removal until this depth, will drastically reduce vegetation resilience. The removal of above- and belowground stems and superficial roots is a common practice in mechanized agriculture. This technique is likely to reduce or exhaust the resilience of vegetation types that depend on resprouting, such as tropical dry forest, caatinga (Sampaio et al., 1993), cerradão (Durigan et al., 1997, 1998) and cerrado stricto sensu (Rezende et al., 2005; Ferreira et al., 2015).

\subsection{Resprouting ability of different species}

Species with high relative densities in all three types of disturbance also dominated old growth forests in the region (Haidar, 2008), suggesting that the dominance of these species is related to a high potential for regeneration through resprouting. Diospyros brasiliensis and Myracrodruon urundeuva are very dense in the region (Haidar, 2008), and were also common in Clear-Cutting area. However, these species had low densities in Stump Removal and Topsoil Stripping areas. Thus, they probably have a high resprouting ability when the stem is present, but low resprouting ability from collar roots and roots. Cupania vernalis, Inga alba, Inga cylindrica and Machaerium hirtum are not dense in the region (Haidar, 2008) and in ClearCutting area, but they were more common in Topsoil Stripping area. These species can be considered strong root resprouters. Given their absence from this study, Casearia rupestris and Centrolobium tomentosum may have low resprouting ability, despite being very dense in the region (Haidar, 2008).

Many studies have shown that the form of secondary succession described for tropical rain or moist forests, based on occupation by pioneer species and subsequent replacement with climax species, does not really occur in tropical and subtropical dry forests (Lebrija-Trejos et al., 2008; Mcdonald et al., 2010; Lévesque et al., 2011). This difference may arise because in dry forests a large portion of the pre-disturbance vegetation persists through resprouting, forming a dense secondary forest within three years after disturbance. This favors seed arrival and germination and seedling establishment of climax tree species. As a result, floristic composition and structure are reestablished within 15-20 years of forest recovery (Lebrija-Trejos et al., 2008; Mcdonald et al., 2010). Therefore, the dynamics of tropical dry forest recovery is compact instead of successional: aerial and underground structures left after the disturbance resprout, providing resilience to the system.

\section{CONCLUSION}

Increasing the severity of disturbance negatively affected the resprouting ability of deciduous forest trees in our study. In Clear-Cutting area, which represented the least severe type of disturbance, resprouts 


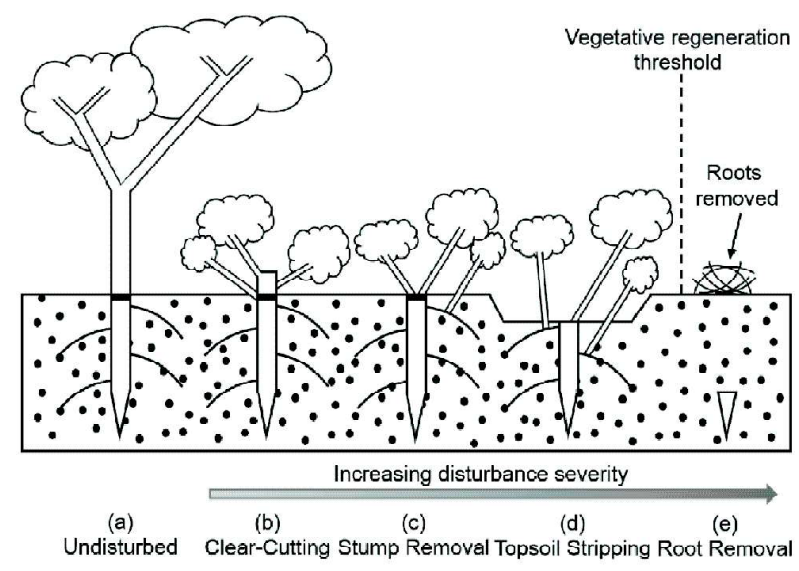

Figure 3 - Diagram of the effects of increasing the severity of anthropogenic disturbance on above- and belowground biomass and on the bud bank (resprouting buds) of trees in a seasonal tropical environment. a, Undisturbed vegetation. b, ClearCutting: resprouts from stumps and root collars dominate. c, Stump Removal: resprouts from root collars and lateral roots dominate. d, Topsoil Stripping: resprouts from lateral and taproots dominate. e, Belowground stem and root removal: the bud bank is suppressed and the vegetation loses resprouting ability. In the figure, resprouts indicate only the position of insertion and not the actual number of resprouts in each type of disturbance.

Figura 3 - Modelo dos efeitos do aumento da severidade de distúrbios de ação humana sobre a biomassa aérea e subterrânea e, sobre as gemas de rebrota (banco de gemas) de plantas lenhosas em ambiente tropical sazonal. a, Vegetação não perturbada. b, Corte raso da vegetação: predomina a rebrota do caule e do colo da raiz. c, Remoção dos tocos (destoca): predomina a rebrota do colo da raiz e da raiz lateral. d, Remoção da camada superficial do solo: predomina a rebrota da raiz lateral e pivotante. e, Remoção de raízes e caules subterrâneos (catação das raízes): o banco de gemas é esgotado acabando com a capacidade de rebrota da vegetação. Na imagem as rebrotas indicam somente a posição de inserção e não o número real rebrotas em cada distúrbio.

from stems dominated; in Stump Removal area (middle level), resprouts from collar root were more prevalent; and in area where the first $20 \mathrm{~cm}$ of soil were removed (high level) resprouts from roots were dominant. Our results indicate that the absence of one structure is compensated by another. Nevertheless, the number of species and resprout density in all types of disturbance studied were able to support the recovery of the forest.
However, if the forest was subjected to more severe disturbance, resilience would decrease. Anadenanthera colubrina, Campomanesia velutina, Dilodendron bipinnatum, Guettarda viburnoides, Platymiscium floribundum and Sebastiania brasiliensis are tree species with great resprouting ability, ensuring that the forest recovery continues, regardless of the type of the perturbation evaluated in our study.

\section{ACKNOWLEDGEMENTS}

We thank Bruno Walter, Ricardo Haidar, João Benedito, Gustavo Paiva and Daniel Chaves for valuable contributions for species identification; Dilmar Brandão, Lívia Moura and Gustavo Mariano for their hearty engagement with fieldwork; and Artur de Paula contributed with ideas for this study. Funding was provided by $\mathrm{CNPq}(\mathrm{MCT} / \mathrm{CNPq} /$ CT-Agronegócio n ${ }^{\circ}$ 26/2010, Proc. 561847/2010-0). MCF had a Masters scholarship from CNPq.

\section{REFERENCES}

Bellingham PJ, Sparrow AD. Resprouting as a life history strategy in woody plant communities. Oikos. 2000;89(2):409-16.

Bond WJ, Midgley JJ. Ecology of sprouting in woody plants: the persistence niche. Trends in Ecology \& Evolution. 2001;16:45-51.

Brasília. Secretaria de Desenvolvimento Urbano e Meio Ambiente do Distrito Federal. ZEE-DF. Relatório do meio físico e biótico. Brasília,DF: 2009. p.14-68.

Clarke P.J., Burrows G.E., Enright N.J., Knox K.J.E. Resprouting as a key functional trait: how buds, protection and resources drive persistence after fire. New Phytologist. 2013;197:19-35.

Del Tredici P. Sprouting in temperate trees: a morphological and ecological review. The Botanical Review. 2001;67:121-40.

Durigan G, Contieri WA, Franco GADC, Garrido MA. Indução do processo de regeneração da vegetação de cerrado em área de pastagem, Assis, SP. Acta Botanica Brasilica. 1998;12:421-9.

Durigan G, Franco GADC, Pastore JA, Aguiar OT. Regeneração natural da vegetação de Cerrado sob floresta de Eucalyptus citriodora. Revista do Instituto Florestal. 1997;9:71-85. 
Ferreira MC, Walter BMT, Vieira DLM. Topsoil translocation for Brazilian savanna restoration: propagation of herbs, shrubs, and trees. Restoration Ecology. 2015;23:723-8.

Gotelli NJ, Colwell RK. Quantifying biodiversity: procedures and pitfalls in the measurement and comparison of species richness. Ecology Letters. 2001;4(10):379-91.

Griscom HP, Ashton MS. Restoration of dry tropical forests in Central America: a review of pattern and process. Forest Ecology and Management. 2011;261(10):1564-79.

Haidar RF. Fitossociologia, diversidade e sua relação com variáveis ambientais em florestas estacionais do bioma Cerrado no planalto central e nordeste do Brasil [dissertação]. Brasília,DF: Universidade de Brasília; 2008.

Hayashi AH, Appezzato-da-Glória B. Resprouting from roots in four Brazilian tree species.

International Journal of Tropical Biology and Conservation. 2009;57(3):789-800.

INMET. Estações e dados: BDMAP - Dados históricos. Estação: 83373- RONCADOR - DF. [acesso em: 15 de maio de 2015]. Disponível em: ttp://www.inmet.gov.br.

Kennard DK, Gould K, Putz FE, Fredericksen TS, Morales F. Effect of disturbance intensity on regeneration mechanisms in a tropical dry forest. Forest Ecology and Management. 2002;162(2):197208.

Klimešová $\mathrm{J}$, Klimeš L. Bud banks and their role in vegetative regeneration-a literature review and proposal for simple classification and assessment. Perspectives in Plant Ecology, Evolution and Systematics. 2007;8(3):115-29.

Lebrija Trejos E, Bongers F, Pérez García EA, Meave JA. Successional change and resilience of a very dry tropical deciduous forest following shifting agriculture. Biotropica. 2008;40(4):422-31.

Lévesque M, Mclaren KP, Mcdonald MA. Recovery and dynamics of a primary tropical dry forest in Jamaica, 10 years after human disturbance. Forest Ecology and Management. 2011;262(5):817-26.
Mazoyer M, Roudart L, Falluh CF. Histórias das agriculturas no mundo: do neolítico à crise contemporânea. São Paulo: UNESP; 2010.

Mcdonald MA, Mclaren KP, Newton AC. What are the mechanisms of regeneration postdisturbance in tropical dry forest? Environmental Evidence. 2010. Disponível em: http://

citeseerx.ist.psu.edu/viewdoc/ download?doi $=10.1 .1 .220 .3317 \&$ rep $=$ rep $1 \&$ type $=$ pdf. [accessed on: 12 feb. 2016.

Mclaren KP, Mcdonald MA. The effects of moisture and shade on seed germination and seedling survival in a tropical dry forest in Jamaica. Forest Ecology and Management. 2003;183(1):61-75.

Mostacedo B, Putz FE, Fredericksen TS, Villca A, Palacios T. Contributions of root and stump sprouts to natural regeneration of a logged tropical dry forest in Bolivia. Forest Ecology and Management. 2009;258(6):978-85.

Murphy PG, Lugo AE. Ecology of tropical dry forest. Annual review of ecology and systematics. $1986 ; 17: 67-88$.

R Core Team. R: A language and environment for statistical computing. Viena: R Foundation for Statistical Computing; 2015. Disponível em: http:// www.R-project.org/.

Rezende AV, Sanquetta CR, Figueiredo Filho A. Efeito do desmatamento no estabelecimento de espécies lenhosas em um cerrado sensu stricto. Floresta. 2005;35(1):69-88.

Ribeiro JF, Walter BMT. As principais fitofisionomias do Bioma Cerrado. In: Sano SM, Almeida SP, Ribeiro JF, organizadores. Cerrado: ecologia e flora. Brasília,DF: Embrapa, Informação Tecnológica; 2008. p.151-212.

Rodrigues RR, Torres RB, Matthes LA, Penha AS. Tree species sprouting from root buds in a semideciduous forest affected by fires. Brazilian Archives of Biology and Technology. 2004;47(1):127-33.

Ruiz J, Fandiño MC, Chazdon RL. Vegetation structure, composition, and species richness across a 56 year chronosequence of dry tropical 
forest on Providencia Island, Colombia. Biotropica. 2005;37(4):520-30.

Sampaio EVSB, Salcedo IH, Kauffman JB. Effect of different fire severities on coppicing of caatinga vegetation in Serra Talhada, PE, Brazil. Biotropica. $1993 ; 25(4): 452-60$

Sampaio AB, Holl KD, Scariot A. Regeneration of seasonal deciduous forest tree species in long used pastures in central Brazil. Biotropica. 2007;39(5):655-9.

Scariot A, Sevilha AC. Biodiversidade, estrutura e conservação de florestas estacionais deciduais no Cerrado. In: Scariot A, Souza-Silva JC, Felfili JM, organizadores. Cerrado: Ecologia, biodiversidade e conservação. Brasília: Ministério do Meio Ambiente, 2005. p.121-39.

SEMARH. APA de cafuringa: a última fronteira natural do DF. Brasília,DF: Secretaria do Meio Ambiente e Recursos Hídricos; 2005.
Sena ALM, Pinto JRR. Regeneração natural em áreas degradadas com enfoque na capacidade de resiliência das espécies lenhosas do cerrado. Anais do $9^{\circ}$ Simpósio Nacional Cerrado. Brasília: 2008.v.9.

Vieira DL, Scariot A, Sampaio AB, Holl KD.

Tropical dry-forest regeneration from root suckers in Central Brazil. Journal of Tropical Ecology. 2006;22(3):353-7.

Vieira DLM, Scariot A. Principles of natural regeneration of tropical dry forests for restoration. Restoration Ecology. 2006a;14:11-20.

Vieira DLM, Scariot A. Effects of logging, liana tangles and pasture on seed fate of dry forest tree species in Central Brazil. Forest Ecology and Management. 2006b;230(1):197-205.

Vieira DLM, Scariot A, Holl KD. Effects of habitat, cattle grazing and selective logging on seedling survival and growth in dry forests of Central Brazil. Biotropica. 2007;39(2):269-74. 